\title{
Antagonism of PII signalling by the AmtB protein of Escherichia coli
}

Timothy A. Blauwkamp and Alexander J. Ninfa* Department of Biological Chemistry, University of Michigan Medical School, 1301 E. Catherine, Ann Arbor, MI 48109-0606, USA.

\section{Summary}

Escherichia coli AmtB is a member of the MEP/Amt family of ammonia transporters found in archaea, eubacteria, fungi, plants and animals. In prokaryotes, AmtB homologues are co-transcribed with a PII paralogue, GInK, in response to nitrogen limitation. Here, we show that AmtB antagonizes PII signalling through NRII and that co-expression of GInK with AmtB overcomes this antagonism. In cells lacking GInK, expression of AmtB during nitrogen starvation prevented deinduction of Ntr gene expression when a nitrogen source became available. The absence of AmtB in cells lacking GInK allowed rapid reduction of Ntr gene expression during this transition, indicating that one function of GInK is to prevent AmtB-mediated antagonism of PII signalling after nitrogen starvation. Other roles of GInK in controlling Ntr gene expression and maintaining viability during nitrogen starvation were unaffected by AmtB. Expression of AmtB from a constitutive promoter under nitrogen-rich conditions induced full expression of gInALG and elevated expression of $g / n K$ in wild-type and gInK cells; thus, the ability of AmtB to raise Ntr gene expression did not require a factor found only in nitrogen-starved cells. Experiments with intact cells showed that AmtB acted downstream of a uridylyl transferase uridylylremoving enzyme (UTase/UR) and upstream of NRII, suggesting that the target was PII. AmtB also slowed the deuridylylation of PII UMP upon ammonia addition, showing that multiple PII interactions were affected by AmtB. Our data are consistent with a hypothesis that AmtB interacts with PII and GInK, and that co-transcription of $g / n K$ and $a m t B$ prevents titration of PII when AmtB is highly expressed.

Accepted 22 January, 2003. *For correspondence. E-mail aninfa@umich.edu; Tel. (+1) 734763 8065; Fax (+1) 7347634581.

\section{Introduction}

The nitrogen regulatory (Ntr) system of Escherichia coli facilitates the efficient assimilation of nitrogen atoms from a variety of compounds containing reduced nitrogen into glutamine and glutamate (for reviews, see Merrick and Edwards, 1995; Ninfa et al., 2000). At high concentrations, ammonia enters cells without the help of Ntr gene products, and basal levels of glutamine synthetase (GS; encoded by $g(n A)$ convert the ammonia to glutamine at a rate that does not limit the growth rate. The intracellular glutamine concentration is detected by the product of the glnD gene, a bifunctional uridylyl-transferase/uridylylremoving enzyme (UTase/UR) that catalyses the addition and removal of uridylyl groups from the signal transduction protein PII (encoded by $g / n B$ ). The non-uridylylated form of PII, present when the glutamine concentration is high, activates the phosphatase activity of the twocomponent system 'transmitter' protein NRII (NtrB, the product of $g(n L)$, which in turn dephosphorylates the 'receiver' protein NRI (NtrC, the product of $g / n G$ ), thereby preventing the activation of Ntr genes by NRI P. During nitrogen limitation, the intracellular concentration of glutamine is low (Ikeda et al., 1996). Uridylylation of PII by the UTase/UR at low intracellular glutamine concentrations prevents PII from activating the phosphatase activity of NRII. Under these conditions, kinase activity of NRII phosphorylates NRI, which activates the transcription of genes whose products facilitate the scavenging of nitrogen atoms from various compounds containing reduced nitrogen (Zimmer et al., 2000).

The Ntr promoters exhibit different sensitivities to transcriptional activation by NRI P, resulting in a defined sequence of activation with increasing NRI $P$ concentrations (Feng et al., 1995; Atkinson et al., 2002a). gInALG transcription is the most sensitive to activation by NRI P and, at low intracellular glutamine concentrations, a positive feedback loop results, in which the levels of NRII and $\mathrm{NRI}$ are rapidly increased and NRI is phosphorylated. Elevated NRI P levels are required for the transcription of operons such as glnKamtB and nac that have less efficient enhancers than gInALG (Atkinson et al., 2002a). Expression of $g / n K$ under conditions of nitrogen limitation results in the appearance of GlnK, a PII paralogue that 
interacts with NRII similar to PII (Atkinson and Ninfa, 1999; Atkinson et al., 2002b) and is reversibly uridylylated by UTase/UR similar to PII (van Heeswijk et al., 1996; Atkinson and Ninfa, 1999).

Previous work with an in frame glnK deletion mutant $\left(g / n K^{-} a m t B^{+}\right)$identified several roles for the GInK protein during the transition between various states of nitrogen availability (Blauwkamp and Ninfa, 2002a). Wild-type cells that became starved for nitrogen upon consumption of a limited amount of ammonia expressed Ntr genes for only about $4 \mathrm{~h}$ after the onset of nitrogen starvation. In the absence of GlnK, cells continued to express Ntr genes for at least $16 \mathrm{~h}$ after the onset of nitrogen starvation, suggesting that GInK is required for the regulation of Ntr genes during nitrogen starvation. Furthermore, in the absence of GInK, cells lost viability much faster than wild-type cells during nitrogen starvation and were unable to turn off Ntr gene expression when a nitrogen source(s) became available (Blauwkamp and Ninfa, 2002a). This persistent Ntr gene expression resulted in a Nac-mediated growth defect that lasted for at least 8 days (Blauwkamp and Ninfa, 2002b). In other words, GInK prevents a very strong and debilitating memory of nitrogen starvation in E. coli.

The inclusion of $g / n K$ and $a m t B$ in a single operon in a number of prokaryotes and the nitrogen-regulated transcription of this operon suggest a possible interaction between GInK and AmtB during nitrogen limitation (Dandekar et al., 1998; Thomas et al., 2000). AmtB is a member of the Mep/Amt family of membrane transporters, and homologues have been identified in eubacteria, archaea, fungi, plants, protists and recently humans; however, the exact role(s) in E. coli remain(s) unclear (Saier et al., 1999; Marini et al., 2000; Thomas et al., 2000). The Saccharomyces cerevisiae AmtB homologues, MEP1, MEP2 and MEP3, have been shown to be high-affinity ammonia transporters (Marini et al., 1994; 1997). Corynebacterium glutamicum contains two Mep/Amt proteins, Amt and AmtB, which transport (methyl)ammonium (charged species only) and ammonium or ammonia respectively (Meier-Wagner et al., 2001). Soupene et al. (2002a) have presented evidence that Salmonella typhimurium AmtB facilitates diffusion of ammonia (uncharged species only) across the cytoplasmic membrane and that E. coli AmtB is required for growth in liquid culture at ammonia (uncharged species) concentrations < $50 \mathrm{nM}$. In addition to roles in ammonia transport, roles for Mep/Amt proteins in signal transduction have also been suggested for MEP2 in S. cerevisiae and for AmtB in Rhodobacter capsulatus (Lorenz and Heitman, 1998; Yakunin and Hallenbeck, 2002). Recently, a nitrogen-regulated interaction between GInK and AmtB in E. coli has been reported based on the observation that GInK associated with the membrane fraction of cell lysates in an AmtB-dependent manner (Coutts et al., 2002). These results led the authors to hypothesize that AmtB interacts directly with GlnK (Coutts et al., 2002).

In this work, we explored the roles of AmtB in the memory of nitrogen starvation, as well as its roles in ammonia sensing and signalling through the Ntr system. Our data show that AmtB expression is the cause of the debilitating memory of nitrogen starvation in cells lacking GInK, and that AmtB antagonizes PII and GInK signalling through NRII independent of the presence of ammonia. AmtB had no role in limiting Ntr gene expression during nitrogen starvation or in maintaining cell viability during nitrogen starvation in these experiments. Our results provide a molecular explanation for the conserved stoichiometric expression of $g / n K$ and $a m t B$ observed in all prokaryotes that have an AmtB homologue.

\section{Results}

AmtB imposes a GInK requirement for recovery from nitrogen starvation

Previous results have shown that GInK was essential for controlling Ntr gene expression during nitrogen starvation and lowering Ntr gene expression when nitrogen-starved cells were fed ammonia (Blauwkamp and Ninfa 2002a; Fig. 1). Here, we examined the role of $A m t B$ in these processes. In order to probe the effects of GInK and AmtB on Ntr induction during nitrogen-rich, nitrogen-starved and post-starvation nitrogen-rich conditions, cells were grown with a growth yield limiting the concentration of ammonia $(0.005 \%)$, held in the starved state and then provided with ammonia by dilution into fresh medium, and the expression of a $g / n K p-l a c Z Y A$ transcriptional fusion $(g \ln K p \phi)$ was monitored during the various growth phases. As shown in Fig. 1, wild-type cells grew rapidly without Ntr induction to an $\mathrm{OD}_{600}$ of $\approx 0.2$, after which cell growth slowed as a result of the consumption of the ammonia, and Ntr gene transcription was induced for $\approx 4 \mathrm{~h}$ before ceasing again (Fig. 1, circles and solid bars). Similar to the wild type, cells containing an in frame deletion of $g / n K$, strain $\mathrm{K}_{3}\left(\right.$ glnK $\left.\mathrm{K}^{-} \mathrm{amtB} \mathrm{B}^{+}\right)$, also grew rapidly without $\mathrm{Ntr}$ induction to an $\mathrm{OD}_{600}$ of $\approx 0.2$, but thereafter expressed Ntr genes continuously for at least $16 \mathrm{~h}$ (Fig. 1, squares and hollow bars). The rate of $\beta$-galactosidase accumulation did not differ significantly between wild type and $\mathrm{K}_{3}$ $\left(g l n K^{-} a m t B^{+}\right)$cells (Table 1). However, as strain $\mathrm{K}_{3}\left(g l n K^{-}\right.$ $\left.a m t B^{+}\right)$did not shut off Ntr gene expression, it accumulated glnK promoter-driven $\beta$-galactosidase to levels approximately five times higher than those observed in wild-type cells (Fig. 1). When diluted into fresh media containing the same initial concentration of ammonia $(0.005 \%)$, wild-type cells immediately resumed rapid growth and shut off Ntr gene expression, whereas strain $\mathrm{K}_{3}\left(g_{\operatorname{lnK}}^{-} a m t B^{+}\right)$lagged before resuming growth at a 


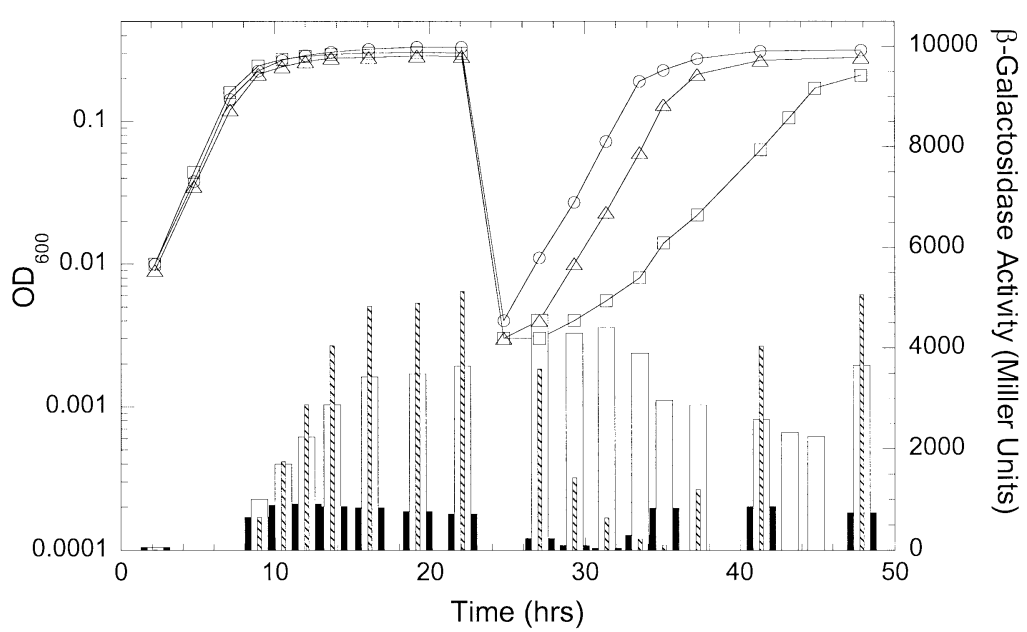

Fig. 1. Expression of $g \operatorname{lnKp} \phi$ as the availability of ammonia changes. The optical density (line graph) and $\beta$-galactosidase activity (bar graph) of cells containing a single copy of the $g / n K p \phi$ were plotted as a function of time for cultures grown with $0.005 \%$ ammonium sulphate as the sole nitrogen source. Cells became nitrogen starved at $\approx 9 \mathrm{~h}$, were held in the nitrogenstarved state for $\approx 13 \mathrm{~h}$ and subcultured into identical media (nitrogen-rich) near $25 \mathrm{~h}$ as shown by the drop in optical density. Wild type, circles and solid bars; $\mathrm{K}_{3}\left(g / n K^{-} a m t B^{+}\right)$, squares and hollow bars; $\mathrm{K}_{2}\left(\right.$ glnK $\left.^{-} a m t B^{-}\right)$, triangles and hatched bars. much slower rate and did not turn off Ntr gene expression (Table 1; Fig. 1). Strain $\mathrm{K}_{2}$, containing a deletion from the middle of $m d l$ to the middle of $a m t B\left(g / n K^{-} a m t B^{-}\right)$, behaved similar to strain $\mathrm{K}_{3}\left(g / n K^{-} a m t B^{+}\right)$before dilution in that it grew rapidly without Ntr induction on the limited ammonia supply and expressed Ntr genes for at least $16 \mathrm{~h}$ after consumption of the ammonia (Fig. 1, triangles and hatched bars). Unlike strain $\mathrm{K}_{3}\left(g / n K^{-} a m t B^{+}\right)$, strain $\mathrm{K}_{2}$ $\left(g / n K^{-} a m t B^{-}\right)$rapidly lowered $\mathrm{Ntr}$ gene expression after dilution into fresh media and resumed rapid growth at the wild-type rate after a brief lag (Fig. 1; Table 1). Thus, GlnK was required in all cases to control Ntr gene expression during nitrogen starvation, but was only required to reduce Ntr gene expression and permit rapid growth after nitrogen starvation when AmtB was present.

To be sure that the GlnK and AmtB phenotypes were not specific to ammonia depletion and addition, we performed analogous experiments with glutamine as the sole nitrogen source. Glutamine at $0.04 \%(\mathrm{w} / \mathrm{v})$ is not nitrogen limiting until the cells reach an $\mathrm{OD}_{600}$ of $\approx 0.2$ (Atkinson et al. 2002a; this work). Cells were grown with $0.04 \%$ glutamine as the sole nitrogen source for $\approx 16 \mathrm{~h}$ to an $\mathrm{OD}_{600} \approx 1.3$ and diluted into fresh media containing $0.04 \%$ glutamine as the sole nitrogen source. As in the ammonia run-out experiments, strains lacking GlnK, regardless of AmtB presence, accumulated threefold higher levels of $\beta$ galactosidase activity expressed from the gInK promoter during the nitrogen starvation phase than wild-type cells (Fig. 2). Upon dilution into fresh media identical to the original growth media, wild-type cells and strain $\mathrm{K}_{2}\left(g / n K^{-}\right.$ $\left.a m t B^{-}\right)$immediately resumed growth and turned off Ntr gene expression until they reached an $\mathrm{OD}_{600}$ of $\approx 0.2$, after which Ntr gene transcription was activated again (Fig. 2; Table 2). In contrast, strain $\mathrm{K}_{3}\left(\mathrm{~g} / \mathrm{n} \mathrm{K}^{-} a m t B^{+}\right)$grew poorly and failed to lower Ntr gene expression when diluted into fresh media, analogous to the situation observed in the ammonia run-out experiments (Fig. 2; Table 2).

The poor growth of strain $\mathrm{K}_{3}\left(\mathrm{glnK}^{-} a m t B^{+}\right)$after starvation is also evident on solid defined media (Blauwkamp and Ninfa, 2002a). In order to determine whether AmtB contributed to the memory of nitrogen starvation in strain $\mathrm{K}_{3}\left(\mathrm{glnK}^{-} \mathrm{amtB} \mathrm{B}^{+}\right)$on solid media, samples of nitrogenstarved cells were plated on nitrogen-rich solid media and the colony sizes were observed. As observed in liquid media, strain $\mathrm{K}_{3}\left(\mathrm{glnK}^{-} \mathrm{amtB} \mathrm{B}^{+}\right)$grew poorly, producing pinpoint colonies barely visible in Fig. 3 , and deletion of AmtB (strains $\mathrm{K}_{2}$ and $\mathrm{K}_{4}$, both $g / n K^{-} a m t^{-}$) relieved the poststarvation growth defect (Fig. 3). Wild-type, $\mathrm{K}_{2}$ and $\mathrm{K}_{3}$ cells starved as described above were also plated on solid media containing either glutamine, ammonia and glutamine or glutamine and glutamate as the nitrogen source(s) and, in all cases, wild-type and $\mathrm{K}_{2}\left(g / n K^{-} a m t B^{-}\right)$ cells grew rapidly, whereas $\mathrm{K}_{3}\left(\mathrm{glnK}^{-} a m t B^{+}\right)$cells grew as poorly as those shown in Fig. 2 (data not shown). As

Table 1. Effects of AmtB on glnK promoter firing rate during ammonia exhaustion.

\begin{tabular}{|c|c|c|c|c|}
\hline \multirow[b]{2}{*}{ Strain } & \multicolumn{3}{|c|}{$\begin{array}{c}\text { glnK promoter firing rate } \\
\left(\Delta \beta \text {-galactosidase units } / \mathrm{h} / 10^{9} \text { cells }\right)^{a}\end{array}$} & \multirow{2}{*}{$\begin{array}{l}\begin{array}{c}\text { Doubling } \\
\text { time (min) }\end{array} \\
\begin{array}{l}\mathrm{NH}_{3} \text {-rich } \\
\text { (post-starv.) }\end{array}\end{array}$} \\
\hline & $\begin{array}{l}\mathrm{NH}_{3} \text {-rich } \\
\text { (prestarv.) }\end{array}$ & $\begin{array}{l}\text { Max. } \mathrm{NH}_{3} \text {-poor } \\
\text { (during starv.) }\end{array}$ & $\begin{array}{l}\mathrm{NH}_{3} \text {-rich } \\
\text { (post-starv.) }\end{array}$ & \\
\hline WT & $<5$ & 437 & $<5$ & 92 \\
\hline $\mathrm{K}_{3}\left(g \ln K^{-} a m t B^{+}\right)$ & $<5$ & 515 & 550 & 153 \\
\hline $\mathrm{K}_{2}\left(g \ln K^{-} a m t B^{-}\right)$ & $<5$ & 836 & $<5$ & 87 \\
\hline
\end{tabular}

a. Values shown were calculated using the data in Fig. 1. 


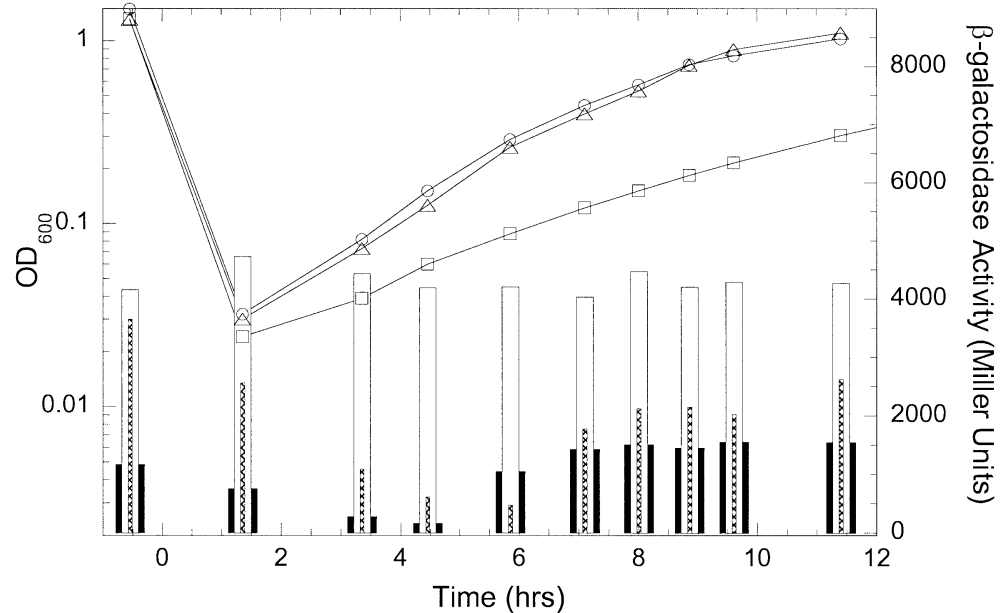

Fig. 2. Expression of $g \ln K p \phi$ as the availability of glutamine changes. The optical density (line graph) and $\beta$-galactosidase activity (bar graph) of cells containing a single copy of the glnKp $\phi$ were plotted as a function of time for cultures grown with $0.4 \%$ glutamine as the sole nitrogen source. Overnight cultures were diluted 1:100 into identical media (nitrogen-rich before OD of 0.2 , nitrogen poor thereafter) and grown for $10 \mathrm{~h} . t_{0}=$ time of subculture after $12 \mathrm{~h}$ of nitrogen starvation. Wild type, circles and solid bars; $\mathrm{K}_{3}\left(g / n K^{-} a m t B^{+}\right)$, squares and hollow bars; $\mathrm{K}_{2}$ $\left(g / n K^{-} a m t B^{+}\right)$, triangles and hatched bars. observed previously, the plate containing strain $\mathrm{K}_{3}\left(g \ln \mathrm{K}^{-}\right.$ $a m t B^{+}$) has two distinct populations of colonies: a number of pinpoint colonies that approximates the number of colonies on the other plates and a few large colonies. We refer to the large colonies as 'fugitives' because we showed previously that they are not mutants, but have somehow escaped nitrogen starvation (Blauwkamp and Ninfa, 2002a). When resubjected to nitrogen starvation, the 'fugitives' grow very poorly in liquid and on solid media, like the original strain (Blauwkamp and Ninfa, 2002a).

Additional experiments showed that the upstream $\mathrm{mdl}$ gene, used in some of the genetic manipulations, did not play a role in the GlnK and AmtB phenotypes. We constructed two additional strains; strain $\mathrm{MK}_{3}$ [glnKp $\left.\phi\right]$ contains the in frame glnK deletion of strain $\mathrm{K}_{3}$ plus an insertion mutation in $m d l$, and strain $\mathrm{K}_{4}$ contains the in frame deletion of strain $\mathrm{K}_{3}$ plus an insertion mutation in $a m t B$. In ammonia run-out experiments similar to those described above, strain $\mathrm{K}_{4}\left(m \mathrm{Il}^{+} \mathrm{g} / n \mathrm{~K}^{-} \mathrm{amtB^{- }}\right)$ behaved exactly like strain $\mathrm{K}_{2}\left(\mathrm{mdl}^{-} \mathrm{gln} \mathrm{K}^{-} a m \mathrm{~B}^{-}\right)$(Fig. 3), whereas strain $\mathrm{MK}_{3}[g / n K p \phi]\left(m l^{-} g l n K^{-} a m t B^{+}\right)$behaved exactly like strain $\mathrm{K}_{3}\left(\mathrm{mdl}^{+} \mathrm{glnK^{- }} a m t B^{+}\right)$(data not shown).

Previous results have shown that cells lacking GlnK have a viability defect during nitrogen starvation (Blauwkamp and Ninfa, 2002a). It is evident from Figs 1 and 2 that the presence of AmtB has very little effect on the role of GlnK in limiting Ntr gene expression during nitrogen starvation, so we probed the role of AmtB in maintaining viability under these conditions. We tested the viability of wild-type, $\mathrm{K}_{2}\left(g / n K^{-} a m t B^{-}\right), \mathrm{K}_{3}\left(g / n K^{-} a m t B^{+}\right)$and $a m t B$ strains after $35 \mathrm{~h}$ of nitrogen starvation. We found no difference in the viability of strains $\mathrm{K}_{2}\left(g / n K^{-} a m t B^{-}\right)$and $\mathrm{K}_{3}\left(g / n K^{-} a m t B^{+}\right)$, both of these strains having $\approx 200$-fold fewer colony-forming units (cfu) than wild-type and amtB strains, despite the similar optical densities of all four strains (data not shown).

\section{AmtB influences Ntr gene expression}

As AmtB prevented deinduction of the Ntr system after nitrogen starvation in cells lacking GlnK, we tested whether AmtB caused elevated Ntr gene expression when ex-pressed from a constitutive promoter under nitrogenrich conditions. The entire coding region of $a m t B$ from 57 nucleotides upstream of the start codon to 83 nucleotides downstream of the stop codon was cloned into the leaky IPTG-inducible vector, $p \operatorname{Trc} 99 \mathrm{~A}$, to yield plasmid pAmtB1 (Experimental procedures). Similar to reported results using different expression systems (Blakely et al., 2002; Soupene et al., 2002b), IPTG induction of AmtB expression from pAmtB1 was toxic to $E$. coli. This toxicity had nothing to do with the expression of Ntr genes, as it was also observed in cells lacking NRI (data not shown). However, the level of AmtB expressed from the leaky Trc

Table 2. Effects of AmtB on glnK promoter firing rate during glutamine exhaustion.

\begin{tabular}{|c|c|c|c|c|}
\hline \multirow[b]{2}{*}{ Strain } & \multicolumn{2}{|c|}{$\begin{array}{c}\text { glnK promoter firing rate } \\
(\Delta \beta \text {-galactosidase } \\
\left.\text { units } \mathrm{h}^{-1} 10^{-9} \text { cells }\right)^{\mathrm{a}}\end{array}$} & \multicolumn{2}{|c|}{ Doubling time (min) } \\
\hline & Preshift & Post-shift & Preshift & Post-shift \\
\hline WT & $>5$ & 905 & 85 & 136 \\
\hline $\mathrm{K}_{3}\left(g / n K^{-} a m t B^{+}\right)$ & 1116 & 996 & 146 & 220 \\
\hline $\mathrm{K}_{2}\left(g \ln K^{-} a m t B^{-}\right)$ & $>5$ & 1411 & 82 & 127 \\
\hline
\end{tabular}

a. Values shown were calculated using the data in Fig. 2. 


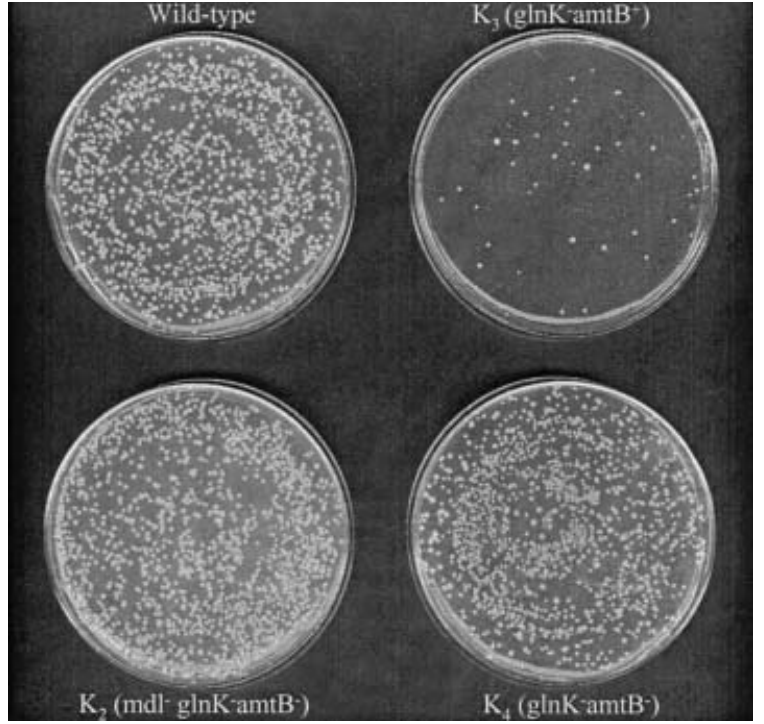

Fig. 3. Memory of nitrogen starvation. Cells of the indicated genotype were grown in media containing $0.005 \%$ ammonium sulphate as the sole nitrogen source, held in the nitrogen-starved state for $\approx 12 \mathrm{~h}$, diluted with sterile water and grown on solid media containing $0.2 \%$ ammonium sulphate as the sole nitrogen source for $40 \mathrm{~h}$ at $37^{\circ} \mathrm{C}$.

promoter in the absence of IPTG was not toxic to wildtype cells and significantly affected Ntr gene expression. In wild-type cells, uninduced (leaky) expression of amtB from pAmtB1 caused full induction of the $g \ln A$ promoter and partial induction of the $g / n K$ promoter on nitrogen-rich media containing ammonia and glutamine, as measured by transcriptional fusions of lacZYA to both promoters (Table 3). In strain $\mathrm{K}_{2}\left(g / n K^{-} a m t B^{-}\right)$, pAmtB1 fully induced gInA promoter expression and raised glnK promoter transcription at least 400 -fold relative to the vector alone, an effect 10 times greater than that observed in the wild-type strain (Table 3). pAmtB1 also caused a growth defect in strain $\mathrm{K}_{2}\left(g / n K^{-} a m t B^{-}\right)$that was not observed in the wild type (Table 3).
Previous results have shown that strong constitutive Ntr gene expression caused a growth defect resulting from Nac-mediated repression of serA that could be relieved by deletion of nac or inclusion of glycine in the growth media (Blauwkamp and Ninfa, 2002b). Either inclusion of glycine in the growth media (Table 3) or deletion of Nac (Table 4) relieved the growth defect of strain $\mathrm{K}_{2}\left(g / n K^{-}\right.$ $a m t B^{-}$) harbouring pAmtB1, suggesting that AmtB raised Ntr gene expression to the point at which Nac significantly inhibited serA expression. A strain identical to $\mathrm{K}_{2}\left(g \ln K^{-}\right.$ $\left.a m t B^{-}\right)$, except containing an in frame deletion within $g / n L$, was transformed with $\mathrm{pAmtB1}$, and this strain did not show elevated Ntr gene transcription or the growth defect, consistent with the above hypothesis (Table 4). Thus, AmtB directly or indirectly influenced the activity of NRII.

To determine whether AmtB influenced NRII activity by limiting the availability of nitrogen, such as by facilitating the exit of ammonia/ammonium from the cell, the effect of AmtB expression from pAmtB1 was monitored in strain $\mathrm{K}_{2} \mathrm{D}\left(g / n K^{-} a m t B^{-} g / n D^{-}\right)$. This strain lacks UTase/UR and cannot transmit a low nitrogen signal to NRI/NRI via PII uridylylation (Bueno et al., 1985; Atkinson and Ninfa, 1998). Expression of $A m t B$ in $K_{2} D$ caused the same growth defects and elevated Ntr gene expression as it did in strain $\mathrm{K}_{2}$ (Table 3). These data suggest that the elevated Ntr gene expression was not a result of limited intracellular nitrogen availability. These data also show that AmtB did not affect Ntr gene expression by altering the activity of UTase/UR towards PII.

\section{AmtB influenced Ntr gene expression regardless of ammonia presence}

Reports of nitrogen-sensing roles for AmtB in R. capsulatus and MEP2 in S. cerevisiae prompted us to explore the possible dependence of AmtB phenotypes on the presence of ammonia (Lorenz and Heitman, 1998; Yakunin and Hallenbeck, 2002). We found that AmtB raised the

Table 3. Effects of AmtB on growth and Ntr-regulated gene expression.

\begin{tabular}{|c|c|c|c|c|}
\hline \multirow[b]{2}{*}{ Strain } & \multicolumn{2}{|c|}{ Doubling time (min) } & \multicolumn{2}{|c|}{$\beta$-Galactosidase activity (Miller units) } \\
\hline & GNg & GNg \pm Gly & GNg & GNg \pm Gly \\
\hline WT-gInAp $\phi$ [ptrc99a] & 120 & 67 & 79 & 71 \\
\hline $\mathrm{K}_{2}-g \ln A p \phi[p t r c 99 a]$ & 128 & 72 & 63 & 53 \\
\hline $\mathrm{K}_{2} \mathrm{D}-g \ln A p \phi[p \operatorname{trc} 99 \mathrm{a}]$ & 141 & 74 & 33 & 32 \\
\hline 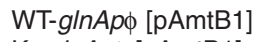 & 110 & 75 & 2406 & 2032 \\
\hline $\mathrm{K}_{2}-g \ln A p \phi[\mathrm{pAmtB} 1]$ & 216 & 83 & 2825 & 2918 \\
\hline $\mathrm{K}_{2} \mathrm{D}-g \ln A p \phi[p A m t \mathrm{~B} 1]$ & 233 & 88 & 3087 & 3366 \\
\hline WT-glnKpф [ptrc99a] & 124 & 72 & 0 & 0 \\
\hline $\mathrm{K}_{2}-g \ln K p \phi[p t r c 99 a]$ & 125 & 73 & 0 & 0 \\
\hline $\mathrm{K}_{2} \mathrm{D}-g \ln K p \phi[p \operatorname{trc} 99 \mathrm{a}]$ & 135 & 77 & 0 & 0 \\
\hline WT-gInKp $\phi[p A m t B 1]$ & 101 & 71 & 252 & 102 \\
\hline $\mathrm{K}_{2}-g \ln K p \phi[\mathrm{pAmtB} 1]$ & 226 & 81 & 3050 & 2207 \\
\hline $\mathrm{K}_{2} \mathrm{D}-g \ln K p \phi[p A m t \mathrm{~B} 1]$ & 231 & 78 & 2807 & 1991 \\
\hline
\end{tabular}

(C) 2003 Blackwell Publishing Ltd, Molecular Microbiology, 48, 1017-1028 
Table 4. AmtB signals upstream of NRI.

\begin{tabular}{|c|c|c|}
\hline Strain & $\begin{array}{l}\text { Doubling time } \\
\text { (min) }\end{array}$ & $\begin{array}{l}\beta \text {-Galactosidase } \\
\text { activity (Miller units) }\end{array}$ \\
\hline WT-gInAp $\phi$ [ptrc99a] & 97 & 57 \\
\hline WT-gInAp $\phi[p A m t B 1]$ & 93 & 2281 \\
\hline LG-g/nAp $\phi$ [ptrc99a] & 91 & 24 \\
\hline LG-glnAp $\phi[p A m t B 1]$ & 93 & 27 \\
\hline L-glnApф [ptrc99a] & 87 & 38 \\
\hline L-glnAp $\phi[\mathrm{pAmtB} 1]$ & 91 & 32 \\
\hline $\mathrm{K}_{2} \mathrm{~N}_{1}$ [ptrc99a] & 91 & ND \\
\hline $\mathrm{K}_{2} \mathrm{~N}_{1}$ [pAmtB1] & 94 & ND \\
\hline
\end{tabular}

expression of the $g \ln A$ promoter equally well in LB media with and without the addition of ammonia, and in defined media containing glutamine or both glutamine and ammonia as nitrogen sources (Table 5). However, as shown in Fig. 2 and reported previously (Atkinson et al., 2002a), media containing $0.04 \%$ glutamine as the sole nitrogen source do not become nitrogen limiting until an approximate $\mathrm{OD}_{600}$ of 0.2 , consistent with the possibility that these media may contain a small amount of ammonia that is consumed as the cells grow. Therefore, to ensure that the cells were growing in the absence of ammonia, the effect of AmtB on Ntr gene expression was monitored in cells grown on $0.04 \%$ glutamine well before ('preshift') and after ('post-shift') the optical density at which Ntr gene expression was induced in wild-type cells. As cells grown with glutamine as the sole nitrogen source ('post-shift') have elevated Ntr gene transcription regardless of AmtB presence, we examined the effects of AmtB in cells lacking $g \ln D$, in which Ntr gene expression is low. As shown in Table 5, pAmtB1 raised the expression of $g \operatorname{lnAp\phi }$ in cells lacking UTase/UR, even in the absence of ammonia. Thus, the AmtB activity detected in our physiology experiments was not regulated by ammonia.

\section{PII and GInK antagonize AmtB similarly}

The results presented thus far suggest that AmtB antagonizes both PII and GInK. To date, all the different functions of PII and GInK in E. coli have been found to result from differences in their timing of expression and level of accumulation (Atkinson et al., 2002b; Blauwkamp and Ninfa, 2002a). We explored the relative abilities of PII and
GlnK to abrogate AmtB effects on Ntr induction. We described previously the construction of a gene fusion containing PII expressed from the glnK promoter and have shown that the timing and level of PII expression was very similar to that of GInK when both were expressed from the glnK promoter (Atkinson et al., $2002 b)$. In the present work, the glnK promoter-driven PII and the analogous glnK promoter-driven GInK were placed onto the chromosome of strain $\mathrm{K}_{2}\left(g_{\ln K^{-}} a m t B^{-}\right)$in single copy, and the expression of a separate single-copy glnKp-lacZYA fusion was monitored (Experimental procedures). The extent to which pAmtB1 raised the steadystate Ntr gene expression level in wild-type cells and cells containing PII or GInK expressed from the glnK promoter is shown in Table 6 . Only slightly higher $(\approx 2.4$-fold $)$ levels of Ntr gene expression were observed when PII was expressed from the glnK promoter instead of GlnK. Relative to the $>10$-fold elevation in Ntr gene expression in cells lacking an inducible PII/GInK (Table 3), this 2.4fold difference suggests that PII and GInK overcame AmtB antagonism similarly.

\section{AmtB slows the deuridylylation of PII UMP}

To explore why glnK $K^{-} a m t B^{+}$strains fail to lower Ntr gene expression upon addition of ammonia to nitrogen-starved cultures, we investigated the kinetics of PII deuridylylation under these conditions. All strains, regardless of GInK or AmtB presence, uridylylated PII during the nitrogen starvation phase as shown 10 min before ammonia addition (Fig. 4, $t_{0}=$ ammonia addition). After the addition of ammonia, wild-type cells took $\approx 1 \mathrm{~h}$ to deuridylylate PII completely. Strain $\mathrm{K}_{3}\left(g \ln \mathrm{K}^{-} a m t^{+}\right)$also took $\approx 1 \mathrm{~h}$ to deuridylylate PII completely. Strain $\mathrm{K}_{4}\left(g / n K^{-} a m t B^{-}\right)$and strain $\mathrm{K}_{2}$ ( mdll $^{-}$glnK $^{-} a m t B^{-}$; data not shown) took $<1 \mathrm{~min}$ to deuridylylate PII. Strain $X\left(g / n K^{+} a m t B^{-}\right)$took $<15 \mathrm{~min}$ to deuridylylate PII. Interestingly, strains lacking AmtB did not completely deuridylylate PII even after $2 \mathrm{~h}$ despite their faster initial rate of deuridylylation. These results show that both AmtB and GInK influence the kinetics of PII deuridylylation, although these differences fail to explain the growth phenotypes of these strains. Wild-type growth differs most significantly from $\mathrm{K}_{3}\left(\mathrm{glnK}^{-} a m t B^{+}\right)$ growth, yet the PII deuridylylation kinetics are similar for these strains. Furthermore, wild-type deuridylylation kinet-

Table 5. Ammonia is not required for AmtB signalling.

\begin{tabular}{|c|c|c|c|c|c|}
\hline \multirow[b]{2}{*}{ Strain } & \multicolumn{5}{|c|}{$\beta$-Galactosidase activity (Miller units) } \\
\hline & LB & LBN & GNgln & Ggln (preshift) & Ggln (post-shift) \\
\hline WT-gInAp $\phi$ [ptrc99a] & 37 & 69 & 79 & 428 & 4152 \\
\hline WT-gInAp $\phi$ [pAmtB1] & 1433 & 1697 & 2406 & 2144 & 4486 \\
\hline D- $g \ln A \mathrm{p} \phi[\mathrm{ptrc} 99 \mathrm{a}]$ & ND & ND & ND & 186 & 623 \\
\hline $\mathrm{D}-g \ln A \mathrm{p} \phi[\mathrm{pAmtB}]$ & ND & ND & ND & 1426 & 1988 \\
\hline
\end{tabular}


Table 6. Relative effects of GInK and PII on AmtB function.

\begin{tabular}{lcc}
\hline Strain & $\begin{array}{l}\text { Doubling time } \\
(\mathrm{min})\end{array}$ & $\begin{array}{l}\beta \text {-Galactosidase } \\
\text { activity (Miller units) }\end{array}$ \\
\hline WT [ptrc99a] & 90 & 0 \\
TAB11812 (glnKpK) [ptrc99a] & 99 & 0 \\
TAB11814 (glnKpB) [ptrc99a] & 104 & 0 \\
WT [pAmtB1] & 91 & 204 \\
TAB11812 (glnKpK) [pAmtB1] & 98 & 184 \\
TAB11814 (glnKpB) [pAmtB1] & 102 & 465 \\
\hline
\end{tabular}

ics differ most significantly from $\mathrm{K}_{2}\left(\mathrm{glnK}^{-} a m t B^{-}\right)$, yet these strains show similar growth phenotypes.

\section{Discussion}

Refining the roles of PII, GInK and AmtB in E. coli

In this work, we have explored the roles of PII, GInK and $A m t B$ in nitrogen regulation. We have found that GInK is required to regulate $\mathrm{Ntr}$ gene expression during nitrogen starvation for two reasons. GInK was required, regardless of AmtB, to prevent rapid loss of viability and the associated 'run-away' expression of Ntr genes during nitrogen starvation (Figs 1 and 2; Blauwkamp and Ninfa, 2002a). Additionally, GInK was required to prevent a debilitating memory of nitrogen starvation in cells containing intact amtB (Figs 1-3; Blauwkamp and Ninfa, 2002a). We identified the molecular mechanism imparting the debilitating memory of starvation as the accumulation of disproportionate levels of AmtB relative to GInK. Accumulated AmtB, in the absence of proportional levels of GlnK, prevented PII from lowering Ntr gene expression when a good nitrogen source became available (Tables 1 and 2), probably by titrating PII (see below). This led to constitutive expression of Ntr genes regardless of nitrogen availability and a growth defect caused by Nac repression of serA (Tables 1-4; Blauwkamp and Ninfa, 2002b). This may explain why nearly every prokaryote containing an AmtB homologue also contains a GInK homologue under similar transcriptional control (Thomas et al., 2000). These results show that GInK is required for proper regulation of NRII during nitrogen starvation and for proper regulation of $A m t B$ during the transition from nitrogen starvation to nitrogen-rich growth.

The role of PII was also expanded by this work in that the fixed level of PII was fully capable of regulating the elevated NRII levels associated with nitrogen starvation upon transition from nitrogen starvation to nitrogen-rich growth, as long as the levels of GInK and AmtB were proportional (or completely absent) (Figs 1 and 2, strain $\mathrm{K}_{2}$ ). Although not expected, this result is not that surprising as the PII-activated phosphatase activity of NRII is stronger than the kinase activity, making only a small amount of PII relative to NRII necessary to dephosphorylate NRI P. Additionally, the concentration of NRII rises only to a certain point (Atkinson and Ninfa, 1993), even in the absence of GInK, because of NRI P-mediated gov-
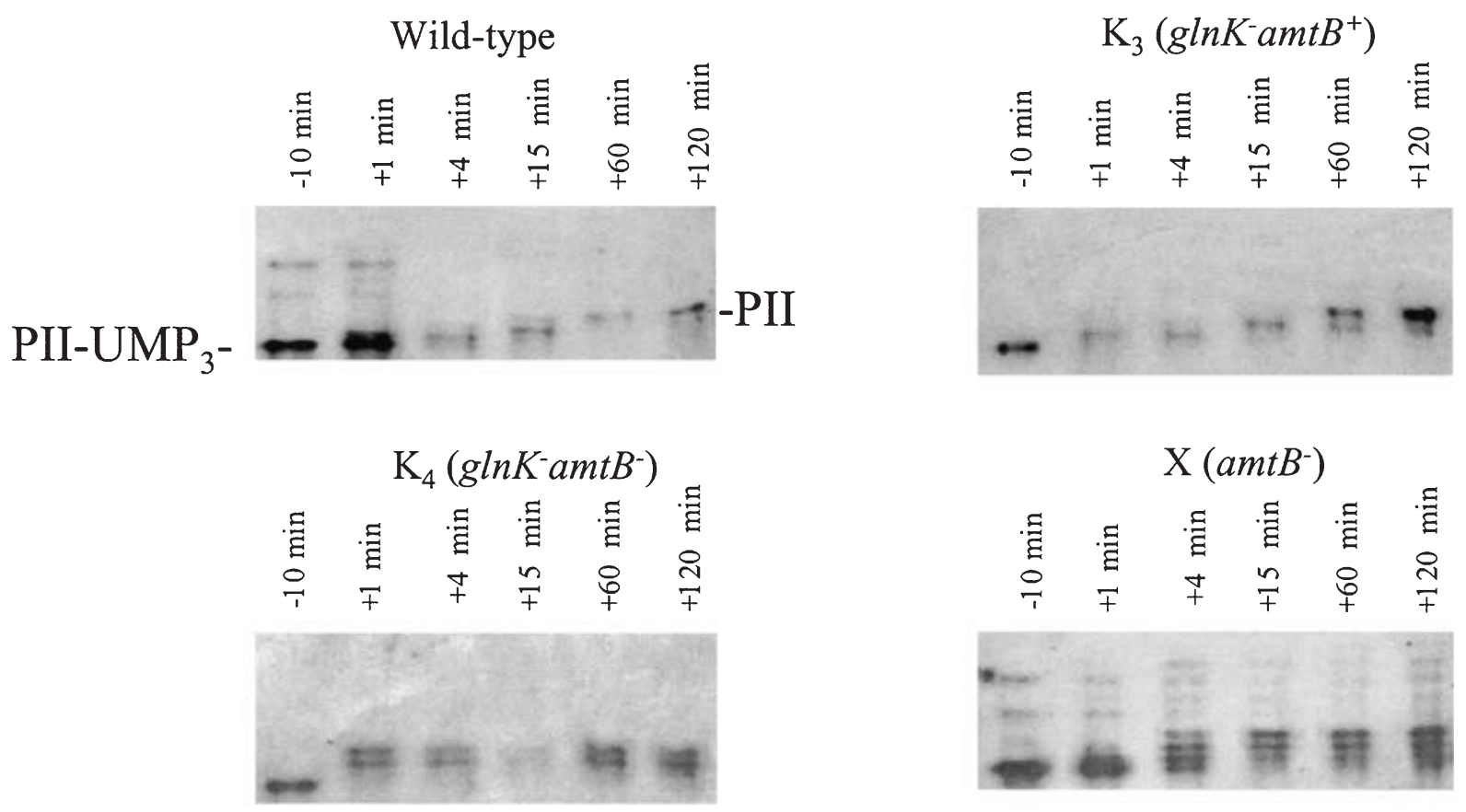

Fig. 4. Kinetics of PII UMP deuridylylation in GInK and AmtB mutants. The uridylylation state of PII was determined before and at various times after the addition of ammonium sulphate $(0.1 \%$ final concentration) to $12 \mathrm{~h}$ nitrogen-starved cells (see Experimental procedures). Time 0 corresponds to the addition of ammonium sulphate. PII was observed by Western blotting with polyclonal antisera against PII. 
ernment of $g \ln A L G$ transcription (Atkinson et al., 2002c; Blauwkamp and Ninfa, 2002a). Apparently, the combination of transcriptional governing of the gInALG operon and strong Pll-activated phosphatase activity prevents the NRII concentration from exceeding the amount that a fixed level of PII can control.

\section{AmtB antagonizes PII and GInK signalling through NRII}

Evidence from this study suggests that AmtB affects Ntr induction in the absence of GInK by sequestering PII. Expression of PII from the glnK promoter abrogated the effect of AmtB expression nearly as well as GInK, suggesting that additional expression of either PII-like protein is sufficient to overcome PII titration by AmtB. Also, using a plasmid that expressed AmtB from the leaky Trc promoter, we observed that AmtB expression raised Ntr gene expression during nitrogen-rich growth as well. However, AmtB did not affect Ntr gene expression in cells lacking NRII, indicating that AmtB signalled through NRII to increase the concentration of NRI P. Expression of AmtB in strains lacking intact UTase/UR, and therefore unable to signal nitrogen starvation to PII or GInK via uridylylation, resulted in elevated Ntr gene expression. This latter result indicates that, although AmtB may still affect intracellular nitrogen availability because of its function as an ammonia permease, changes in the uridylylation state of PII and GInK were not the cause of AmtB-mediated Ntr induction. Taken together, these results show that AmtB acts upstream of NRII and downstream of UTase/UR in the signalling pathway, implying that its target is either PII or NRII.

Formally, hypotheses regarding the mechanism of AmtB-mediated Ntr gene activation can be divided into those that make PII less available for interaction with its receptors (such as changes in $\alpha$-ketoglutarate concentration or titration of free PII by AmtB) and those that do not affect PII activity (such as AmtB activation of NRII kinase activity or competition for a binding site on NRII with PII). We attempted to distinguish the Pll-dependent mechanisms from PII-independent mechanisms by looking for AmtB-mediated effects in cells lacking PII and GInK. Although AmtB expression did not produce any significant change in growth rate or Ntr gene expression in cells lacking PII and GInK, the effects may be masked by the already strong (probably maximal) expression of $\mathrm{Ntr}$ genes in cells lacking PII and GlnK (Blauwkamp and Ninfa, 2002b; data not shown). In support of a PII-dependent mechanism, AmtB also disrupts the interaction of PII UMP with UTase/UR as shown in Fig. 4.

Our results are consistent with and extend the recent results of Coutts et al. (2002), who observed an AmtBdependent association of PII and GInK with the membrane fraction of $E$. coli cell lysates, suggesting that both interact directly with AmtB (Coutts et al., 2002). These workers also reported that GInK regulated the methylammonium transport activity of AmtB twofold; however, our results suggest an alternative interpretation of these data. As shown in Fig. 2, the presence of the non-polar $\Delta$ glnK1 mutation (strain $\mathrm{K}_{3}$ ) resulted in approximately twofold higher levels of glnK promoter expression on media containing glutamine as the sole nitrogen source. As this probably corresponds to a twofold increase in AmtB expression from the glnK promoter, this could account for the reported twofold GInK-dependent increase in methylammonium transport activity in the strains lacking GInK (Coutts et al., 2002). Future experiments should be conducted with purified components to examine whether GInK and PII directly regulate the AmtB permease activity.

If AmtB is a PII/GInK receptor, then its ability to sequester PII upon accumulation to non-physiological levels is consistent with the behaviour of the known PII/GInK receptors. We will show elsewhere that expression of UTase/UR or glutamine synthetase adenyltransferase (ATase) from multicopy plasmids in cells lacking GInK also elevates Ntr gene expression to the point at which these cells behave like cells lacking PII and GInK (unpublished data). Even low expression of a UTase/UR mutant (D105N) with very little enzymatic activity caused full induction of GS expression (A. J. Ninfa and M. R. Atkinson, unpublished data). Furthermore, overexpression of NRII also raised Ntr gene expression under nitrogen-rich conditions (unpublished data). Wild-type cells avoid these complications by controlling the expression of all known PII receptors in a way that prevents them from potentially titrating PII. Expression of $\operatorname{gln} A L G$ is turned off when NRI levels accumulate to a certain point, such that the NRII concentration does not increase to levels more than 10- to 12-fold higher than those observed during nitrogen-rich growth (Atkinson and Ninfa, 1993; Atkinson et al., 2002c, Blauwkamp and Ninfa, 2002a). The $g \ln D$ and $g \ln E$ genes are not nitrogen regulated and are expressed at a constant low level (van Heeswijk et al., 1993). Co-expression of AmtB and GInK at proportional levels ensures enough free PII to regulate all its receptors. Clearly, the levels of PII and its receptors are fine-tuned, and large changes in the relative levels of PII and its receptors are avoided.

Although PII-independent mechanisms for AmtB signalling have not been rigorously excluded, our data are best explained at this time by a model in which proportional amounts of GInK and AmtB are required to prevent AmtB from titrating PII and thereby preventing its interaction with its other receptors such as NRII and UTase/UR.

Revised view of the transitions between nitrogen-excess growth and nitrogen starvation

In view of the recent advances in our understanding of the 
roles of PII, GInK and AmtB, we present the following model of Ntr regulation during the transitions between various states of nitrogen availability. PII is almost entirely responsible for regulating the expression of $\mathrm{Ntr}$ genes during nitrogen-rich growth (Blauwkamp and Ninfa, 2002a; this work). Upon nitrogen limitation, PII is uridylylated, and $g \ln A L G$ expression is induced, resulting in a positive feedback loop that rapidly amplifies the level of $\mathrm{NRII}$ and $\mathrm{NRI}(\sim \mathrm{P})$. NRII and NRI P concentrations are only increased $\approx 10$ - to 12 -fold because high concentrations of NRI P mediate governing of the glnA promoter (Atkinson et al., 2002c). This high concentration of NRI P also induces transcription of less sensitive Ntr genes, including glnKamtB and nac. Uridylylation of PII appears to be complete during starvation as expression of GInK is required to prevent runaway expression of $\mathrm{Ntr}$ genes (other than $g \ln A L G$ ) under these conditions (Blauwkamp and Ninfa, 2002a; this work). GInK acts through NRII to shut off Ntr gene expression in nitrogen-starved cells such that only a short burst of Ntr gene expression occurs after the onset of nitrogen starvation (Fig. 1). The mechanism by which GInK turns off Ntr gene expression after a short burst remains unclear. One possible explanation is that the uridylylation of GInK is incomplete and, upon sufficient accumulation of GInK, the unmodified fraction reaches a concentration able to activate the phosphatase activity of NRII and thereby turn off Ntr gene expression. Failure to limit Ntr gene expression during nitrogen starvation in cells lacking GInK is correlated with a much faster loss of viability under these conditions (Blauwkamp and Ninfa, 2002a). Neither the unchecked Ntr gene expression nor the viability defects of strains lacking GInK is influenced by AmtB expression (Figs 1 and 2; data not shown).

When nitrogen-starved cells are provided with a good nitrogen source, PII and GInK are deuridylylated and activate phosphatase activity of NRII, ensuring that Ntr genes are not expressed. The fixed level of PII is fully capable of ensuring that Ntr genes are not expressed when a good nitrogen source is available; however, the expression of AmtB requires that proportional levels of $\mathrm{GlnK}$ be present to prevent AmtB from titrating PII (Blauwkamp and Ninfa, 2002a; this work).

\section{Multiple roles of AmtB and GInK}

It appears that the presence of the glnKamtB operon in many bacterial species serves multiple purposes. First, it allows cells to assimilate very low concentrations of ammonia during nitrogen starvation (Soupene et al., 2002a) without preventing PII signalling. Secondly, it provides the cell with additional PII-like protein required for optimal cell viability maintenance during nitrogen starvation (Blauwkamp and Ninfa, 2002a). Thirdly, given the likely ability of AmtB to bind PII and GInK, it may also play a role in regulating nitrogen assimilation. The sequestering of GInK by AmtB in the presence of ammonia has been proposed to account for one aspect of nitrogen assimilation in Klebsiella pneumoniae. Unuridylylated GInK prevents NifL inhibition of NifA-mediated transcriptional activation of nif genes (He et al., 1998). Upon addition of ammonia to nitrogen-limited cultures, AmtB binding of unuridylylated GInK has been proposed to sequester GInK, thereby freeing NifL to inhibit NifA (Coutts et al., 2002). The selective binding of unuridylylated PII and GInK by AmtB reported by Coutts et al. (2002) should also modulate GInK and PII interactions with the other PII receptors (UTase/UR, NRII and ATase in E. coli). Furthermore, if ammonia regulated the potential of AmtB to antagonize PII and GInK signalling, AmtB would also provide an additional sensory element to the Ntr system. We did not observe an effect of ammonia on the ability of AmtB to antagonize PII signalling in our experiments. However, in our experiments, the effects of AmtB were detected in cells modestly overexpressing AmtB from either its own promoter $(g \ln K p)$ or from a multicopy plasmid. This level of expression caused dramatic phenotypes, but may have obscured regulation of the AmtB-PII/ GInK interaction by ammonia that may occur at physiological levels of AmtB.

\section{Experimental procedures}

\section{Bacterial strains, plasmids and growth conditions}

Bacterial strains and plasmids used in this study are shown in Table 7. Defined media was W-salts (Pahel et al., 1978) supplemented with $0.005 \%$ thiamine hydrochloride and carbon and nitrogen sources as indicated in the text. Ampicillin $\left(100 \mu \mathrm{g} \mathrm{ml}^{-1}\right)$, kanamycin $\left(50 \mu \mathrm{g} \mathrm{ml}^{-1}\right)$, tetracycline $(20 \mu \mathrm{g}$ $\left.\mathrm{ml}^{-1}\right)$ and gentamicin $\left(10 \mu \mathrm{g} \mathrm{ml}^{-1}\right.$ on W-salts, $50 \mu \mathrm{g} \mathrm{ml}^{-1}$ on LB) were included when appropriate. Preparation of LB media and plasmid transformation were performed as described previously (Maniatis et al., 1982). Plasmid DNA was prepared with the Concert Rapid Plasmid preparation kits (Marligen Bioscience). Generalized transduction was performed as described using P1vir (Silhavy et al., 1984) and used to move the antibiotic marker and linked mutations between strains. All experiments were performed at $37^{\circ} \mathrm{C}$.

\section{Measurement of growth rate and ginK promoter expression during nitrogen-rich, nitrogen-starved and post-starvation nitrogen-rich growth conditions}

For ammonia exhaustion experiments, overnight cultures grown in W-salts supplemented with $0.4 \%$ (w/v) glucose, $0.2 \%(\mathrm{w} / \mathrm{v})$ ammonium sulphate, $0.005 \%$ tryptophan and $50 \mu \mathrm{g} \mathrm{ml}^{-1}$ kanamycin were washed twice and diluted 1:500 into W-salts supplemented as above, except containing $0.005 \%(w / v)$ ammonium sulphate. Samples were removed from the cultures at the indicated times, and the optical density and $\beta$-galactosidase activity were determined. Optical 
Table 7. Strains and plasmids used in this study.

\begin{tabular}{|c|c|c|}
\hline Strain $^{\mathrm{a}}$ & Relevant genotype ${ }^{\mathrm{b}}$ & Source or construction \\
\hline WT (YMC10) & endA1 thi-1 hsdR17 supE44 $\Delta / a c U 169$ hut $C_{\text {klebs }}$ & Backman et al. (1981) \\
\hline WT[ $q \ln K \mathrm{p} \phi](\mathrm{YMC} 10 \phi)$ & 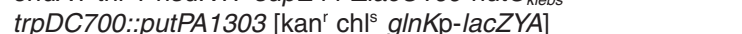 & Atkinson and Ninfa (1998) \\
\hline $\mathrm{K}_{2}[g \ln K p \phi](\mathrm{K} \phi)$ & 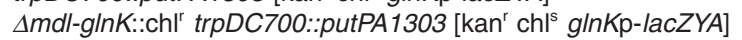 & Atkinson and Ninfa (1998) \\
\hline $\mathrm{K}_{3}[\mathrm{~g} \ln K \mathrm{p} \phi]$ & 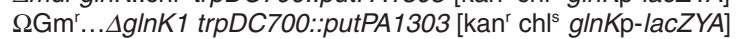 & Blauwkamp and Ninfa (2002b) \\
\hline $\mathrm{K}_{4}[g \ln K \mathrm{p} \phi]$ & $\begin{array}{l}\Omega G m^{r} \ldots . \text { glnK1 amtB::chl' trpDC700::putPA1303 }\left[\mathrm{kan}^{r} \mathrm{chl}^{\mathrm{s}}\right. \\
\text { glnKp-lacZYA] }\end{array}$ & $\begin{array}{l}\text { This work, see Experimental } \\
\text { procedures }\end{array}$ \\
\hline $\mathrm{MK}_{3}[g \ln \mathrm{pp} \phi]$ & 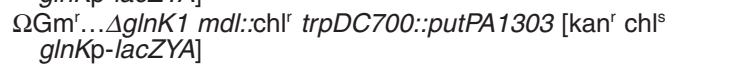 & $\mathrm{K}_{3} \phi \times \mathrm{MAM} \mathrm{P} 1 \mathrm{vir}, \mathrm{Gm}^{+} \mathrm{chl}^{+}$ \\
\hline MAM & recD mdl:: $\mathrm{chl}^{\mathrm{r}}$ & Atkinson and Ninfa (1998) \\
\hline & amtB::chlr & Atkinson and Ninfa (1998) \\
\hline$X[g \ln K p \phi]$ & 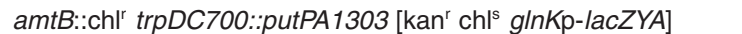 & $\mathrm{WT}[g \ln K \mathrm{p} \phi] \times \mathrm{X} \mathrm{P} 1 \mathrm{vir}$ \\
\hline WT[glnAp2ф] (YMC10Apф2) & 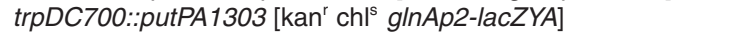 & Atkinson et al. (2002a) \\
\hline $\mathrm{K}_{2}[g \ln A p 2 \phi]$ & $\begin{array}{l}\Delta m d l-a m t B:: \mathrm{chl}^{\mathrm{r}} \operatorname{trpDC700::putPA1303}\left[\mathrm{kan}^{\mathrm{r}} \mathrm{chl}^{\mathrm{s}}\right. \\
\text { glnAp2-lacZYA] }\end{array}$ & WT $[g \ln A p 2 \phi] \times$ MAKc P1 vir \\
\hline MAKc & $\Delta m d l-g \ln K:: \mathrm{chl}^{r}$ & Atkinson and Ninfa (1998) \\
\hline $\mathrm{K}_{2} \mathrm{D}[g \ln A p 2 \phi]$ & $\begin{array}{l}\Delta m d l-a m t B:: \mathrm{chl}^{\mathrm{r}} \text { glnD99::Tn } 10 \text { trpDC700::putPA1303 [kan' } \mathrm{chl}^{\mathrm{s}} \\
\text { glnAp2-lacZYA] }\end{array}$ & $\mathrm{K}_{2}[g \ln A p 2 \phi] \times \mathrm{DE} \mathrm{P} 1$ vir \\
\hline $\mathrm{K}_{2} \mathrm{D}[g \ln K \mathrm{p} \phi]$ & 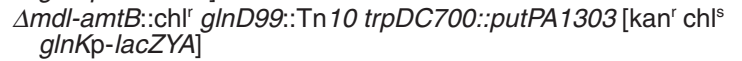 & $\mathrm{K}_{2}[g \ln K p \phi] \times \mathrm{DE} \mathrm{P} 1$ vir \\
\hline DE & $g \ln D 99:: \operatorname{Tn} 10$ glnE::Tn5 & RB9040 $\times$ EB2717 P1 vir \\
\hline RB9040 & gInD99::Tn 10 & Bueno et al. (1985) \\
\hline EB2717 (RB9098) & $\Delta g \ln E:: \operatorname{Tn} 5 \mathrm{~g} \ln L-302$ & B. Magasanik \\
\hline $\mathrm{K}_{2} \mathrm{~N}_{1}$ & $\Delta m d l-a m t B:: \mathrm{chl}^{r}$ nac-28(kan $)$ & MAKc $\times$ EB3365 P1 vir \\
\hline EB3365 & nac-28 $\left(\mathrm{kan}^{\prime}\right)$ & Muse and Bender (1998) \\
\hline L[glnAp2申] & gInL2001 trpDC700::putPA1303 [kan' chls glnAp2-lacZYA] & RB9132 $\times$ MAAplac3 P1 vir \\
\hline RB9132 & gInL2001 & Bueno et al. (1985) \\
\hline MAAplac3 & 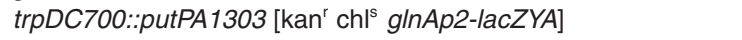 & Atkinson et al. (2002a) \\
\hline $\mathrm{LG}[g \ln A \mathrm{p} 2 \phi]$ & 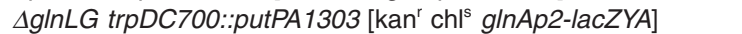 & YMC10LG $\times$ MAAplac3 P1 vir \\
\hline YMC10LG & $\triangle g I n L G$ & YMC10 $\times$ SN24 P1 vir \\
\hline SN24 & 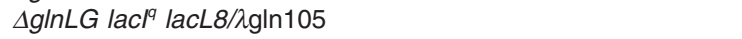 & Schneider et al. (1991) \\
\hline $\mathrm{D}[g \ln A \mathrm{p} 2 \phi]$ & glnD99::Tn 10 & RB9040 $\times$ MAAplac3 P1 vir \\
\hline TAB11812 & 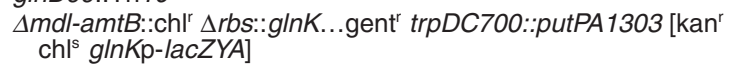 & $\mathrm{K}_{2}[g / n K \mathrm{p} \phi] \times \mathrm{TAB} 11802 \mathrm{P} 1 \mathrm{vir}$ \\
\hline TAB11814 & $\begin{array}{l}\Delta m d l-a m t B:: \text { chl }^{r} \Delta r b s:: \text { glnKp-glnB...gentr } \\
\text { trpDC700::putPA1303 [kan } \mathrm{ch}^{\mathrm{s}} \text { gInKp-lacZYA] }\end{array}$ & $\mathrm{K}_{2}[g \ln K \mathrm{p} \phi] \times \mathrm{TAB} 11804 \mathrm{P} 1 \mathrm{vir}$ \\
\hline TAB11802 & $\begin{array}{l}\text { recD rbs::glnK ...gent }{ }^{r} \text { trpDC700::putPA1303 }\left[\mathrm{kan}^{\mathrm{r}} \mathrm{chl}^{\mathrm{s}}\right. \\
\text { gInKp-lacZYA] }\end{array}$ & K4633 × pGInK101 DNA \\
\hline TAB11804 & $\begin{array}{l}\text { recD rbs:: glnKp-glnB...gent trpDC700::putPA1303 [kan }{ }^{r} \mathrm{chl}^{\mathrm{s}} \\
\text { glnKp-lacZYA] }\end{array}$ & K4633 × pGInKpB101 DNA \\
\hline K4633 & recD::Tn 10 & D. Friedman \\
\hline $\mathrm{BK}_{2}[g \ln K \mathrm{p} \phi]$ & 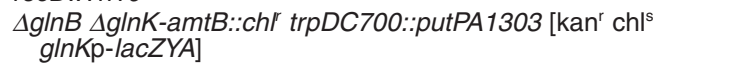 & $\mathrm{B} \phi \times \mathrm{MAKc} \mathrm{P} 1$ vir \\
\hline $\mathrm{B} \phi$ & $\Delta g \ln B$ trpDC700::putPA1303 [kan' chls glnKp-lacZYA] & Atkinson et al. (1998) \\
\hline
\end{tabular}

a. Parentheses bracket strain names as designated in the given reference.

b. All strains were derived from YMC10, except $\mathrm{WCH} 30$ and $\mathrm{K} 4633$.

density at $600 \mathrm{~nm}$ was monitored in a Beckman DU65 spectrophotometer, and $\beta$-galactosidase activity was measured by the Miller assay and expressed as Miller units, using SDS and chloroform to disrupt the cells, as described previously (Miller, 1992). Once the cultures stopped growing and Ntr gene transcription was activated, the cells were considered to be nitrogen starved. Cells were fed nitrogen after nitrogen starvation either by subculturing at 1:100 into fresh media containing $0.005 \%$ ammonium sulphate as the sole nitrogen source or by plating a diluted aliquot of cells from nitrogenstarved cultures on solid media containing $0.4 \%$ glucose, $0.005 \%$ tryptophan and either $0.2 \%$ ammonia, $0.2 \%$ glutamine, $0.2 \%$ ammonia plus $0.2 \%$ glutamine or $0.2 \%$ ammonia plus $0.2 \%$ glutamate as the sole nitrogen source(s). In the glutamine exhaustion experiments, cells were grown as described above, except that $0.04 \%$ glutamine was used instead of ammonia and the cells were not washed. The $\mathrm{glnK}$ promoter firing rate ( $\beta$-galactosidase units $\mathrm{ml}^{-1} \mathrm{~h}^{-1}$ per cell) was determined by dividing the change in $\beta$-galactosidase units $\mathrm{ml}^{-1}$ expressed from the $\mathrm{glnK}$ promoter by the time elapsed between measurements and the change in optical density of the cultures at $600 \mathrm{~nm}$ between measurements, assuming $10^{9}$ cells $\mathrm{ml}^{-1}$ when $\mathrm{OD}_{600}=1$.

The viability of nitrogen-starved cells was determined after $35 \mathrm{~h}$ of nitrogen starvation as described previously (Blauwkamp and Ninfa, 2002a).

\section{Construction of $p A m t B 1$}

The entire coding region of amtB from 57 nucleotides upstream of the start codon to 83 nucleotides downstream of the stop codon was polymerase chain reaction (PCR) amplified from strain N2 using primers AmtB-US (CGGAATTCCGGCACA CAGCAACAGGAACG) and AmtB-DS (CGGGATCCCGT TCAGGAAGGGGTGATGCG). This PCR fragment was cloned into the pTrc99A vector (Amersham Pharmacia Biotech), containing the leaky IPTG-inducible Trc promoter and plasmid- 
encoded $l a c l^{q}$, at the $E c o R I$ and $B a m H I$ sites. DNA sequencing at the University of Michigan DNA Sequencing core confirmed the wild-type sequence of the $a m t B$ gene and $5^{\prime}$ untranslated region.

\section{Construction of glnKp fusions to the glnK and glnB structural genes}

A novel vector, pRBS3a, facilitating recombination of cloned genes linked to gentamicin resistance into a transcriptionally isolated landing pad in the rbs operon of $E$. coli was generously provided by M. R. Atkinson and will be described in detail elsewhere. We have described previously the construction of plasmids that contain the promoter region of $g / n K$ fused to the start codon of either $g \operatorname{lnK}$ (pglnK81) or $g \ln B$ (pglnKpB1) via an engineered Nde1 restriction site at the start codon (Atkinson et al., 2002b). Klenow end-filled BamHI fragments of pglnK81 and pglnKpB1 containing the promotergene fusions were cloned into a Klenow-blunted Pst1 site in pRBS3a to yield plasmids pglnK101 and pglnKpB101 respectively. A sample of $0.5 \mu \mathrm{g}$ of pglnK101 and pglnKpB101 plasmid DNA was linearized by Notl digestion and electroporated into strain K4633. Gentamicin-resistant transformants were screened for the correct size insert in the rbs operon by PCR using primers that anneal outside the cloned region and confirmed recombination into the rbs operon.

\section{Determination of Pll deuridylylation kinetics}

Overnight cultures of the indicated strains grown in W-salts containing $0.4 \%$ glucose, $0.2 \%$ ammonium sulphate, $0.005 \%$ trp and $50 \mu \mathrm{g} \mathrm{ml}^{-1}$ kanamycin were diluted 1:300 into media identical to that described above except containing $0.008 \%$ ammonium sulphate. Cells were grown for $23 \mathrm{~h}$ at $37^{\circ} \mathrm{C}$ to ensure consumption of the ammonia. At the times indicated in the text, aliquots of cells were removed into EDTA (50 mM final concentration) to kill UTase/UR activity, sonicated for $25 \mathrm{~s}$ on power 3 (Branson sonifier 250) and frozen in a dry ice-isopropanol bath. The time from removal of the cell sample to freezing was $\approx 1 \mathrm{~min}$. Frozen samples were placed at $65^{\circ} \mathrm{C}$ for $20 \mathrm{~min}$ to destroy any remaining UTase/UR activity without disrupting PII( UMP) trimers, and the supernate was collected after a 10 min centrifugation at $12000 \mathrm{~g}$. Supernatant protein $(7 \mu \mathrm{g})$ was resolved by $16 \%$ PAGE, and the uridylylation state of PII was determined by immunoblotting as described previously (Atkinson et al., 2002b).

\section{Determination of AmtB effects on growth and Ntr gene expression}

Cultures $(25 \mathrm{ml})$ of cells of the indicated genotype harbouring either pTrc99A (empty vector) or pAmtB1 were grown from single isolated colonies in W-salts containing $0.2 \%$ ammonium sulphate, $0.2 \%$ glutamine and $0.1 \%$ glycine as indicated in the text. Cell growth was monitored in a Beckman DU-65 spectrophotometer, and $\beta$-galactosidase activity expressed from $g \ln A$ or $g \ln K$ promoter fusions to lacZYA was determined at an $\mathrm{OD}_{600}$ of $\approx 0.4$ by the Miller assay and expressed as Miller units, using SDS and chloroform to disrupt the cells, as described previously (Miller,
1992). The standard deviation of the $\beta$-galactosidase assays was $<15 \%$ for all experiments.

\section{Acknowledgements}

We thank Bob Bender and Boris Magasanik for helpful discussions and bacterial strains. This work was supported by grant GM57393 from the NIH-NIGMS.

\section{References}

Atkinson, M.R., and Ninfa, A.J. (1993) Mutational analysis of the bacterial signal-transducing protein kinase/phosphatase nitrogen regulator II $\left(\mathrm{NR}_{\|}\right.$or $\left.\mathrm{NtrB}\right)$. J Bacteriol 175: 7016-7023.

Atkinson, M.R., and Ninfa, A.J. (1998) Role of the GInK signal transduction protein in the regulation of nitrogen assimilation in Escherichia coli. Mol Microbiol 29: 431-447.

Atkinson, M.R., and Ninfa, A.J. (1999) Characterization of the GInK protein of Escherichia coli. Mol Microbiol 32: 301313.

Atkinson, M.R., Blauwkamp, T.A., Bondarenko, V.A., Studitsky, V.M., and Ninfa, A.J. (2002a) Activation of the glnA, glnK, and nac promoters as Escherichia coli makes the transition from growth on ammonia to nitrogen starvation. J Bacteriol 184: 5358-5363.

Atkinson, M.R., Blauwkamp, T.A., and Ninfa, A.J. (2002b) Context-dependent functions of the PII and GInK signaltransduction proteins in Escherichia coli. J Bacteriol 184: 5364-5375.

Atkinson, M.R., Pattaramannon, N., and Ninfa, A.J. (2002c) Governor of the glnAp2 promoter of Escherichia coli. Mol Microbiol 46: 1247-1257.

Backman, K., Chen, Y.-M., and Magasanik, B. (1981) Physical and genetic characterization of the $g \ln A-g \ln G$ region of the Escherichia coli chromosome. Proc Natl Acad Sci USA 78: 3743-3747.

Blakely, D., Leech, A., Thomas, G.H., Coutts, G., Findlay, K., and Merrick, M. (2002) Purification of the Escherichia coli ammonium transporter AmtB reveals a trimeric stoichiometry. Biochem J 364: 527-535.

Blauwkamp, T.A., and Ninfa, A.J. (2002a) Physiological role of the GInK signal transduction protein of Escherichia coli: survival of nitrogen starvation. Mol Microbiol 46: 203-214.

Blauwkamp, T.A., and Ninfa, A.J. (2002b) Nac-mediated repression of the serA promoter of Escherichia coli. Mol Microbiol 45: 351-363.

Bueno, R., Pahel, G., and Magasanik, B. (1985) Role of glnB and gInD gene products in regulation of the gInALG operon of Escherichia coli. J Bacteriol 164: 816-822.

Coutts, G., Thomas, G., Blakey, D., and Merrick, M. (2002) Membrane sequestration of the signal transduction protein GInK by the ammonium transporter AmtB. EMBO J 21: 536-545.

Dandekar, T., Snel, B., Huynen, M., and Bork, P. (1998) Conservation of gene order: a fingerprint of proteins that physically interact. Trends Biochem Sci 23: 324-328.

Feng, J., Goss, T.J., Bender, R.A., and Ninfa, A.J. (1995) Activation of transcription initiation from the nac promoter of Klebsiella aerogenes. J Bacteriol 174: 245-253.

He, L., Soupene, E., Ninfa, A., and Kustu, S. (1998) Physiological role for the GInK protein of enteric bacteria: relief of 
NifL inhibition under nitrogen-limiting conditions. $J$ Bacteriol 180: 6661-6667.

van Heeswijk, W.C., Rabenberg, M., Westerhoff, H.V., and Kahn, D. (1993) The genes of the glutamine synthetase adenylylation cascade are not regulated by nitrogen in Escherichia coli. Mol Microbiol 9: 443-457.

van Heeswijk, W.C., Hoving, S., Molenaar, D., Stegeman, B., Kahn, D., and Westerhoff, H.V. (1996) An alternative PII protein in the regulation of glutamine synthetase in Escherichia coli. Mol Microbiol 21: 133-146.

Ikeda, T.P., Shauger, A.E., and Kustu, S. (1996) Salmonella typhimurium apparently perceives external nitrogen limitation as internal glutamine limitation. J Mol Biol 259: 589607.

Lorenz, M.C., and Heitman, J. (1998) The MEP2 ammonium permease regulates pseudohyphal differentiation in Saccharomyces cerevisiae. EMBO J 17: 1236-1247.

Maniatis, T.I., Fritsch, E.F., and Sambrook, J. (1982) Molecular Cloning: A Laboratory Manual. Cold Spring Harbor, NY: Cold Spring Harbor Laboratory Press, pp. 68 and 250.

Marini, A.-M., Vissers, S., Urrestarazu, A., and Andre, B. (1994) Cloning and expression of the MEP1 gene encoding an ammonium transporter in Saccharomyces cerevisiae. EMBO J 13: 3456-3463.

Marini, A.-M., Soussi-Boudekou, S., Vissers, S., and Andre, B. (1997) A family of ammonium transporters in Saccharomyces cerevisiae. Mol Cell Biol 17: 4282-4293.

Marini, A.-M., Matassi, G., Raynal, V., Andre, B., Cartron, J.P., and Cherif-Zahar, B. (2000) The human Rhesus-bloodgroup associated RhAG protein and a novel kidney homologue promote ammonium transport in yeast. Nature Genet 26: 341-344.

Meier-Wagner, J., Nolden, L., Joakoby, M., Siewe, R., Kramer, R., and Burkovski, A. (2001) Multiplicity of ammonium uptake systems in Corynebacterium glutamicum: role of Amt and AmtB. Microbiology 147: 135-143.

Merrick, M.J., and Edwards, R.A. (1995) Nitrogen control in bacteria. Microbiol Rev 59 (4): 604-622.

Miller, J.H. (1992) A Short Course in Bacterial Genetics. A Laboratory Manual and Handbook for Escherichia coli and Related Bacteria. Cold Spring Harbor, NY: Cold Spring Harbor Laboratory Press, pp. 72-74.
Muse, W.B., and Bender, R.A. (1998) The nac (nitrogen assimilation control) gene from Escherichia coli. J Bacteriol 180: 1166-1173.

Ninfa, A.J., Jiang, P., Atkinson, M.R., and Peliska, J.A. (2000) Integration of antagonistic signals in the regulation of nitrogen assimilation in Escherichia coli. Curr Topics Cell Regul 36: 31-75.

Pahel, G., Zelentz, A.D., and Tyler, B.M. (1978) gltB gene and regulation of nitrogen metabolism by glutamine synthetase in Escherichia coli. J Bacteriol 133: 139-148.

Saier, M.H., Jr, Eng, B.H., Fard, S., Garg, J., Haggerty, D.A., Hutchinson, W.J., et al. (1999) Phylogenetic characterization of novel transport protein families revealed by genome analysis. Biochim Biophys Acta 1422: 1-56.

Schneider, B.L., Shiau, S.P., and Reitzer, L.J. (1991) Role of multiple environmental stimuli in control of transcription from a nitrogen-regulated promoter in Escherichia coli with weak or no activator-binding sites. J Bacteriol 173: 63556363.

Silhavy, T.J., Berman, M.L., and Enquist, L.W. (1984) Experiments with Gene Fusions. Cold Spring Harbor, NY: Cold Spring Harbor Laboratory Press, pp. 107-112.

Soupene, E., Lee, H., and Kustu, S. (2002a) Ammonium/ methylammonium transport (Amt) proteins facilitate diffusion of $\mathrm{NH}_{3}$ bidirectionally. Proc Natl Acad Sci USA 99: 3926-3931.

Soupene, E., Chu, T., Corbin, W., Hunt, D.F., and Kustu, S. (2002b) Gas channels for $\mathrm{NH}_{3}$ : proteins from hyperthermophiles complement an Escherichia coli mutant. J Bacteriol 184: 3396-3400.

Thomas, G., Coutts, G., and Merrick, M. (2000) The glnKamtB operon: a conserved gene pair in prokaryotes. Trends Genet 16: 11-14.

Yakunin, A.F., and Hallenbeck, P.C. (2002) AmtB is necessary for $\mathrm{NH}_{4}{ }^{+}$-induced nitrogenase switch-off and ADPribosylation in Rhodobacter capsulatus. J Bacteriol 184: 4081-4088.

Zimmer, D.P., Soupene, E., Lee, H.L., Wendisch, V.F., Khodursky, A.B., Peter, B.J., et al. (2000) Nitrogen regulatory protein C-controlled genes of Escherichia coli: scavenging as a defense against nitrogen limitation. Proc Natl Acad Sci USA 97: 14674-14679. 